Short communication

\title{
Phytochemical screening of three medicinally important epiphytic orchids of Bangladesh
}

\author{
A. Marjoka, O. Alam and M.K. Huda* \\ Department of Botany, University of Chittagong, Chittagong 4331, Bangladesh
}

Orchids are the largest and most diverse group among the angiosperms and they are mainly cultivated for beautiful flowers (Chowdhery, 1998). They are widely known for their horticultural and commercial importance but less for their medicinal value. Recently there has been tremendous progress in medicinal plants research; however orchids have not been exploited fully for their medicinal application. Medicinal plants produce a vast array of therapeutically important secondary metabolite of the classes, alkaloids, terpenoids and phenols (Hess, 1975; Goodwin and Mercer, 1986; Hopkins, 1999) and have strong physiological activities in the animal systems. For this reason, plants containing secondary metabolites are very important to us as potential ingredient of herbal and many modern medicines.

Traditional Chinese medicine widely utilizes orchids in medicines. Some orchid species like Dendrobium crumenative, Eulophia campestris, Orchis latifolia, Vanda roxburghii and Vanda tessellata have been documented for their medicinal value (Chowdhery, 1998). Phytochemically some orchids have been reported to contain alkaloids, terpenoids, flavonoids and stilbenoids (Singh \& Sanjiv, 2009) and more than 44 orchid species of 34 genera have medicinal value (Ghanaksha \& Kaushik, 1993). Orchids are also commercially important for its glycosidal value where four kinds of glycosides have been reported to be present in some orchids (Bose \& Yadav, 1989). Loroglosin from Loroglossum, coumarin from Angraceum fragrance and saponin from Paphiopedilum javanium (Bose \& Yadav, 1989) are commercially important glycosides. Another important and the most popular phenolic aldehyde is vanillin. Vanilla planifolia is the main source of commercial vanilla flavor. In Bangladesh there are 178 orchid taxa and some of these are medicinally important (Huda, 2008). . Of them, 26 species of orchids also been used by the tribal people of Bangladesh to treat different diseases (Huda et al., 2006). The main objective of the present work is to determine the qualitative status of phytochemical properties of three medicinally important epiphytic orchid species which were selected based on the frequent uses of these three species by the tribal people of Chittagong Hill tracts. Three medicinally important epiphytic orchid species viz Acampe papillosa (Lindl.), Lindl., Cymbidium aloifolium (L.) Sw. and Rhyncostylis retusa (L) Blume have been chosen investigated to study their phytochemical properties. Qualitative assessment was performed to study the presence of different secondary metabolites like alkaloids, flavonoids, tannins, saponins, glycosides etc.

*Corresponding author. E-mail: mkhuda70@hotmail.com 
Collection, extraction and phytochemical screening of samples: The leaves of three medicinally important epiphytic orchid species viz, Acampe papillosa, Cymbidium aloifolium and Rhyncostylis retusa were used for the qualitative estimation of alkaloids and seven other secondary metabolites; flavonoids, steriods, phlobatannins, terpenoids, tannins, saponins and glycosides. Firstly these three species viz. Acampe papillosa, Cymbidium aloifolium and Rhyncostylis retusa were collected from field and identified consulting the literatures and confirmed after comparing with the existing herbarium preserved at the Herbarium of Chittagong University (HCU). The voucher specimens of the studied species (accession number AM 7 for Acampe papillosa, AM 9 for Cymbidium aloifolium and AM 3 for Rhyncostylis retusa) have been preserved at the HCU. The leaves of the studied species were thoroughly washed with water and dried in oven at $60^{\circ}$ $\mathrm{C}$ for 48 hours. It was then ground into coarse powder by using grinding machine and stored in airtight container for further investigation. Mixing of one species with other was carefully avoided. $25 \mathrm{gm}$ of samples from each of the species were used for phytochemical analysis.

Qualitative tests were carried out on the fresh sample, powdered specimens and methanol extracted crude using standard procedures to identify the constituents as described by Sofowara (1993), Trease \& Evans (1989), and Harborne (1973). For qualitative test of alkaloids, the most reliable and rapid testing method was developed by Webb (1949) and the method was slightly modified by Aplin \& Canon (1971). Phytochemical screenings of the three epiphytic orchid species for secondary metabolites were analyzed following standard methods. Test for phlobatannins and flavonoids were following Edeoga et al., 2005, test for saponins were following Kapoor et al., 1969, test for tannins was following Harborne, 1973, test for terpenoids and steroids were following Kolawole et al., 2006 and test for glycosides was following Harborne, 1973.

In the present work, the presence of relative alkaloid contents and seven other secondary metabolites in the extract of test plants and/or their organs were expressed by '+' sign ranging in the order of '+', ' ++ ' and ' +++ ' signifying it's presence in degrees (' + ' minimum to ' +++ ', the highest quantity). Absence of the secondary metabolites was denoted by '-' sign. Results are given in the Table 1 by arranging the plant species in alphabetic order.

Table 1. Qualitative test for alkaloids and seven secondary metabolites in the leaves of three epiphytic orchid species

\begin{tabular}{|c|c|c|c|c|c|c|c|c|c|c|c|c|}
\hline \multirow[t]{2}{*}{$\begin{array}{c}\text { Name of the } \\
\text { species }\end{array}$} & \multicolumn{5}{|c|}{$\begin{array}{l}\text { Qualitative estimation of } \\
\text { alkaloids } \\
\text { (by different reagents) }\end{array}$} & \multicolumn{7}{|c|}{ Secondary metabolites } \\
\hline & $\mathrm{D}$ & $\mathrm{H}$ & $\mathrm{M}$ & $\mathrm{T}$ & $\mathrm{W}$ & Gly. & Flv. & Phl. & Sap. & Tan. & Ter. & Str. \\
\hline $\begin{array}{l}\text { Acampe } \\
\text { papillosa }\end{array}$ & +++ & + & + & ++ & + & + & + & - & +++ & ++ & - & + \\
\hline $\begin{array}{l}\text { Cymbidium } \\
\text { aloifolium }\end{array}$ & ++ & + & + & +++ & ++ & - & + & - & ++ & + & ++ & + \\
\hline $\begin{array}{l}\text { Rhyncostylis } \\
\text { retusa }\end{array}$ & +++ & + & ++ & +++ & ++ & + & +++ & ++ & + & ++ & +++ & + \\
\hline
\end{tabular}


The results of the Table 1 indicated that, different species of orchids showed positive response for different type of reagents. In Acampe papillosa, Dragendroff's reagent (D) showed '+++', Hager's reagent $(\mathrm{H})$ '+', Mayer's reagent (M) '+', Tannic acid reagent (T) '++' and Wagner's reagent (W) '+' indicating presence of alkaloids. In Cymbidium aloifolium, Dragendroff's reagent (D) showed '++', Hager's reagent (H) '+', Mayer's reagent $(\mathrm{M})$ ' + ', Tannic acid reagent $(\mathrm{T})$ ' +++ ' and Wagner's reagent $(\mathrm{W})$ ' ++ ' also indicating presence of alkaloids. In Rhyncostylis retusa, Dragendroff's reagent (D), Hager's reagent $(\mathrm{H})$, Mayer's reagent $(\mathrm{M})$, Tannic acid reagent $(\mathrm{T})$ and Wagner's reagent (W) showed '+' to '+++' revealed the presence of alkaloids.

The results of the table 1 also indicated that, Acampe papillosa exhibited the presence of different secondary metabolites with their intensity following '+++' with saponins, '++' with tannins, ' + ' with glycosides, flavonoids and steroids. Phlobatannins and terpenoids were absent in Acampe papillosa. Whereas, Cymbidium aloifolium showed '++' with saponins and terpenoids, '+' with flavonoids, tannins and steroids. On the other hand, glycosides and phlobatannins were absent in Cymbidium aloifolium. Rhyncostylis retusa expressed '+++' with flavonoids and terpenoids, '++' with phlobatannins and tannins and '+' with glycosides, saponins and steroids.

Different species showed different test for alkaloids with one or another type of reagents such as: Dragendroff's reagent, Hager's reagent, Mayer's reagent, Tannic acid reagent and Wagner's reagent. Acampe papillosa, showed a total of eight '+', Cymbidium aloifolium showed seven ' + ' and Rhyncostylis retusa showed eleven ' + ' indicating the different level of presence of alkaloids. All the three species exhibited positive response for alkaloids but among them, Rhyncostylis retusa showed higher presence of alkaloids.

Edeoga et al. (2005) examined and compared tannins, saponins, steroids, terpenoids, flavonoids, phlobatannin and cardiac glyciside distribution in ten medicinal plants (e.gCleome rutidosperma, Emilia coccinea, Scoparia dulcis, Sida acuta, Stachytarpheta cayennensis, Tridax procumbens etc.). All contained tannins and flavonoids except $S$. acuta and S. cayennnsis where tannins and flavonoids were absent, respectively. Uneven distribution of all these secondary metabolites in medicinal plants was also reported by others (Krishnaniah et al. 2009, Ayeni et al, 2010, Koche et al, 2010). The occurrence of different secondary metabolites suggested a wide range of biological application of the medicinal plants (Tanrisever et al, 1988). Secondary metabolites may be responsible for many pharmacological action like wound healing (Shivhare et al, 2010), cholesterol lowering (Sharmila et al, 2007) and antidiabetic activities (Rai et al, 2008).

In addition to alkaloids, qualitative assessment for seven other secondary metabolites, e.g. tannin, flavonoids, steroids, phlobatannins, saponins, glycosides and terpenoids were done in three selected epiphytic orchid species. Three epiphytic orchid species such as Acampe papillosa, Cymbidium aloifolium and Rhyncostylis retusa showed different tests for the seven secondary metabolites. Acampe papillosa showed presence of saponins, tannins, glycosides, flavonoids and steroids whereas, Cymbidium aloifolium showed less presence of saponins, terpenoids, flavonoids, tannins and steroids. Rhyncostylis retusa 
revealed better presence of flavonoids, terpenoids, phlobatannins and tannins and less presence of glycosides, saponins and steroids. Phlobatannins and terpenoids were absent in Acampe papillosa, whereas, glycosides and phlobatannins were absent in Cymbidium aloifolium. Among three orchid species, Rhyncostylis retusa exhibited relatively higher presence of seven secondary metabolites (tannin, flavonoids, steroids phlobatannins, saponins, glycosides and terpenoids).

\section{REFERENCES}

Akter, S. 2008. Pharmacognosical investigation on some medicinal plants. M. S. Thisis. Department of Botany, Chittagong University, Chittagong.

Aplin T.E.H. and Cannon, J.R. 1971. Distribution of alkaloids in some Western Australian plants. Economic. Bot. 25(4): 366-380.

Ayeni, K.E. and Yahaya, S.A. 2010. Phytochemical screening of three medicinal plants neem leaf (Azadirachta indica), hibiscus leaf (Hibiscus rosasinensis) and spear grass leaf (Imperata cylendrica). Continental J. Pharmaceutical Science 4: 47-50.

Bose, T.K. and Yadav, L.P. 1989. Commercial Flowers. Naya Prokash, Calcutta. pp. 151-263.

Chowdhery, H.J. 1998. Orchid Flora of Arunachal Pradesh. Bishen Singh Mahaendra Pal Singh, Dehra Dun, India.

Cromwell, B.T. 1955. Modern method of plant analysis. Springer-Verlag. pp. 448-460.

Edeoga, H.O., Okwu, D.E. and Mbaebie, B.O. 2005. Phytochemical constituents of some Nigerian medicinal plants. African J. Biotechnology. 4(7): 685-688.

Goodwin, T.W. and Mercer, E.I. 1986. Introduction to plant biochemistry. $2^{\text {nd }}$ ed. Pergamon press. Oxford. New York. p. 677.

Harbrone, J.B. 1973. Phytochemical methods. Chapman and Hall. Ltd. London. pp. 49-188.

Hess, D. 1975. Plant physiology, molecular, biochemical and physiological fundamentals of metabolism and development. Springer. study ed. Toppan company (s) Pvt. Ltd. Singapore pp. 144.

Hopkins, W.G. 1999. Introduction to plant physiology. 2nd. ed. John Wiley and Sons. Inc. New York. Trovto. pp. 271-278.

Huda, M.K., Rahman, M.A. and Wilcock, C.C. 2006. The ethnobotanical information on indigenous orchids of Bangladesh. The Hamdard Medicus. XLIX, (3): 138-143.

Huda, M.K. 2008. An up to date enumeration of the family Orchidaceae from Bangladesh. $J$. Orchid Soc. India. 21(1-2):35-49.

Kapoor, L.D, Singh, A., Kapoor, S.L. and Shrivastava, S.N. 1969. Survey of Indian medicinal plants for saponins, alkaloids and flavonoids. Lloydia, 32: 297-302.

Ghananksha, A. and Kaushik, P. 1993. Antibacterial effect of Aerides multiflora Roxb. A study In vitro . J. Orchid Soc. India, 13 (1-2):65-68.

Kolawole, O.M., Oguntoye, S.O., Agbede, O. and Olayemi, A.B. 2006. Studies on the efficacy of Bridelia ferruginea Benth. bark extract in reducing the coliform load and BOD of domestic waste water. Ethnobotanical Leaflets, 10: 228-238.

Koche, D., Shirsat., R. Imran, S. and Bhadange, D.G. 2010. Pharmaceutical screening of eight traditionally used ethanomedicinal plants from akola district (ms) India. International Journal of Pharma and Bio Sciences. 2: 253-256.

Krishnaiah, D., T. Devi., A. Bono. and R. Sarbatly. 2009. Studies on phytochemical constituents of six Malaysian medicinal plants. J. Med. Plants Res. 3 (2): 67-72.

Monira, S.S. and Alamgir, A.N.M.. 2008. Investigation on secondary metabolites, cytotoxic effect and antimicrobial activities of some medicinal plants. M.S. Thesis, submitted to the Dept. of Botany, Chittagong University. 
Pasha M.K. 1977. Phytochemical survey of Bangladesh plants, I.A. Preliminary report. Bangladesh J. Bot. 6(1-2): 57-64.

Rai, P. Kumar, J., Dolly, R., Devendra, K., Sharma, B. and Geeta, W. 2008. Effect of water extract of Trichosanthes dioica fruits in Streptozotocin induced diabetic rats. Ind. J. Clinical Biochem, 23 (4): 387-390.

Sharmila, G., Kumar, G. and Rajasekara, K. 2007. Cholesterol-lowering activity of the aqueous fruit extract of Trichosanthes diocia Roxb (L.) in normal and streptozotocin diabetic rats. J. Clinical \& Diag. Res. 1(6): 561-567.

Shivhare, Y., Singour, P., Patil, U.K.. and Pawar, R.S.. 2010. Wound healing potential of methanolic extract of Trichosanthes dioica Roxb (fruits) in rats. J. Ethnopharma. 127: 614-619.

Singh. A and D. Sanjiv. 2009. Medicinal Orchids: An Overview. Ethnobotanical leaflets 13: 351363, 875-877.

Sofowara, A. 1993. Medicinal plants and Traditional medicine in Africa. Spectrum Books Ltd. Ibadan, Nigeria. pp. 289

Tanrisever, N., Fischer, H. and Williamson, G.B. 1988. Methofurans from Calamintha ashei, effects on Schizachyrium scoparium and Lactuca sativa. Phytochemistry. 27(8): 25232526.

Tariq, M., Mossa, J.S., Al-yahya, M.A., Al-meshal, I.A. and Al-badar, A.A. 1987. Phytochemical and biological screening of Saudi medicinal plants. Int. J. Crude Drug. Res. 25 (1)17-25.

Trease, G.E. and Evans, W.C. 1989. Pharmacognosy. 11 th edn. Brailliar Tiridel Can. Macmillian publishers.

Webb, L. J. 1949. An Australian phytochemical survey. C.S.I.R.D. Bull. 260, Melbourne. 